\title{
Causes of debris flow formation in flysch area of North Istria, Croatia
}

\author{
Ž. Arbanas ${ }^{1,2}, \check{C}$. Benac ${ }^{1} \&$ V. Jurak ${ }^{3}$ \\ ${ }^{I}$ Faculty of Civil Engineering, University of Rijeka, Croatia \\ ${ }^{2}$ Civil Engineering Institute of Croatia, Department of Rijeka, Croatia \\ ${ }^{3}$ Faculty of Mining, Geology and Petroleum Engineering, \\ University of Zagreb, Croatia
}

\begin{abstract}
The central and northern parts of the Istrian Peninsula situated in the northwestern part of the Croatian Adriatic coast are formed within the Paleogene flysch rock complex. The flysch zone in the northeastern part of the peninsula borders with the Ćićarija Mountain Range, which mostly consists of carbonate rocks. The occurrences of debris flows that cause huge damage to transport and other constructions are quite frequent. In this paper, we present the causes and triggering mechanisms of debris flows sporadically occurring in the Krbavčići village area near the city of Buzet. The potentially unstable soil mass formed by the erosion of the flysch bedrock fills the narrow and long ravines cut into the flysch bedrock all the way to the limestone slopes of the Ćićarija Mountain Range. This paper describes in detail the occurrence of a particular debris flow along with its repetitive appearances in the period from the winter of 1979 until today. The debris flow mass damaged the road embankment and caused its downslope slide in the length of about $300 \mathrm{~m}$ in one night in the winter of 1979. The movement of the debris mass triggered in the ravine put into danger the bridge constructed over an old unstable zone in the winter of 2003, however fast intervention measures prevented the possible damage.
\end{abstract}

Keywords: debris flow, landslide, flysch, triggering mechanism.

\section{Introduction}

In the northern part of the Istrian Peninsula there is a clearly visible boundary between two geomorphological units, namely the hilly Paleogene flysch basin, 
the so-called Gray Istria, and the elevated Ćićarija Mountain Range, the so-called White Istria. Very steep cliffs form the boundary between these two units. Numerous mass movements such as rockfalls, simple and complex landslides and debris flows were occurred at this location.

The potentially unstable soil deposits formed by the erosion of the flysch bedrock fill the narrow and long ravines cut into the flysch bedrock all the way to the limestone slopes of the Cićarija Mountain Range. During the last four decades these mass movements have caused repeated damage to the railroad track and the roads that exist on the southwestern slopes of the Cićarija Mountain, Fig. 1. The phenomenon of debris flows is especially interesting because they suddenly appear and suddenly stop. This paper describes the phenomenon of debris flows and the triggering mechanisms that cause the instability in the Krbavčići village area near the city of Buzet.

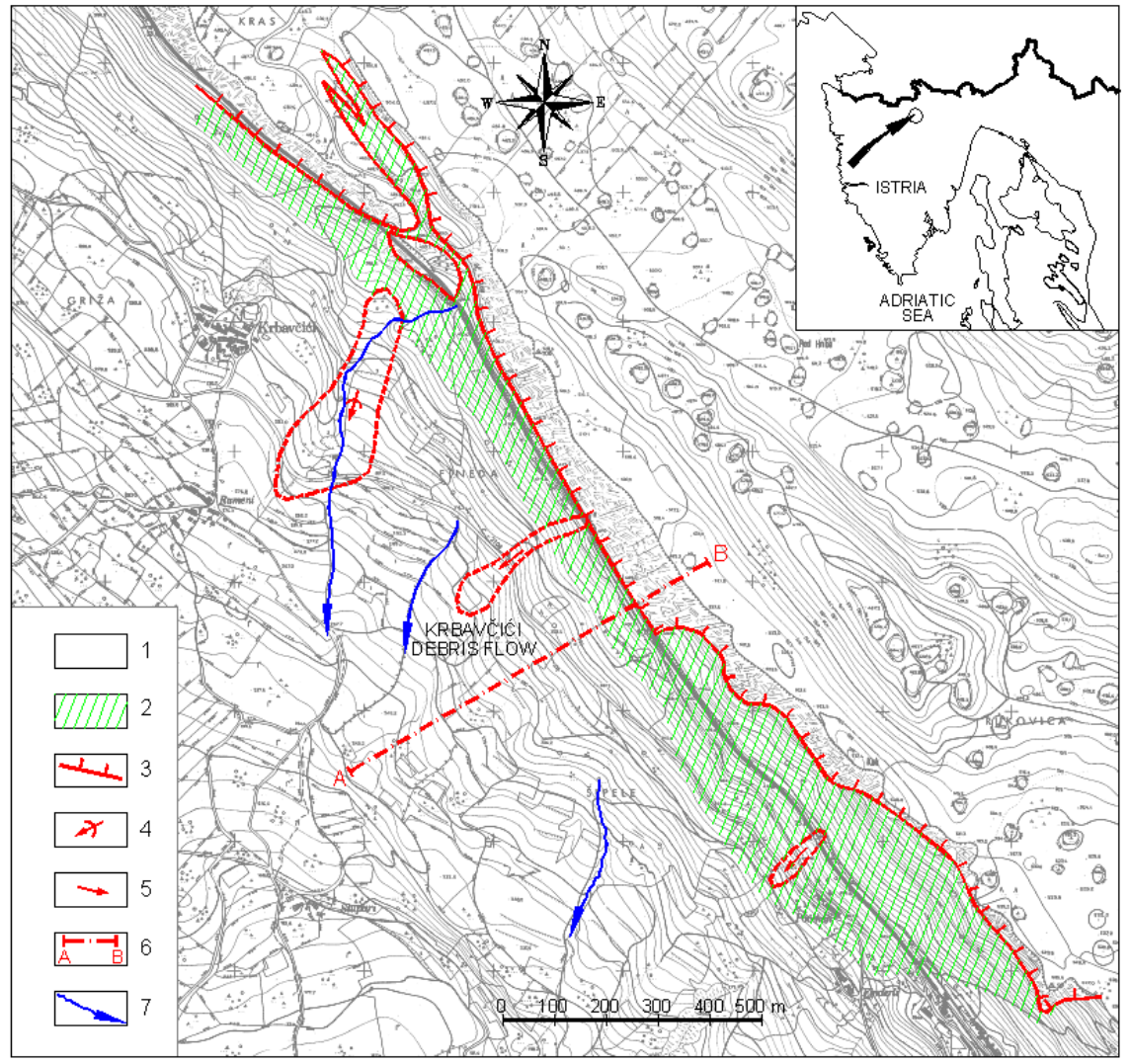

Figure 1: Geological map of investigated area (1. White Istria - Paleogene limestones; 2. Gray Istria - Paleogene marls, flysch and quaternary deposits; 3. Reverse fault; 4. Landslide; 5. Debris flow; 6 . Trace of geological cross-section, see Fig. 2; 7. Creek). 


\section{Geology of studied area}

The geomorphologically dominant elevation of the southwestern margin of the Ćićarija Mountain, the so-called White Istria, was formed within the Paleogene and Creataceous carbonate rock complex. This area is a part of the overthrust structure that stretches in direction NW-SE. The hilly area on the southwestern side is a part of the tectonically slightly disturbed Paleogene flysch basin, the socalled Gray Istria $[1,2]$.

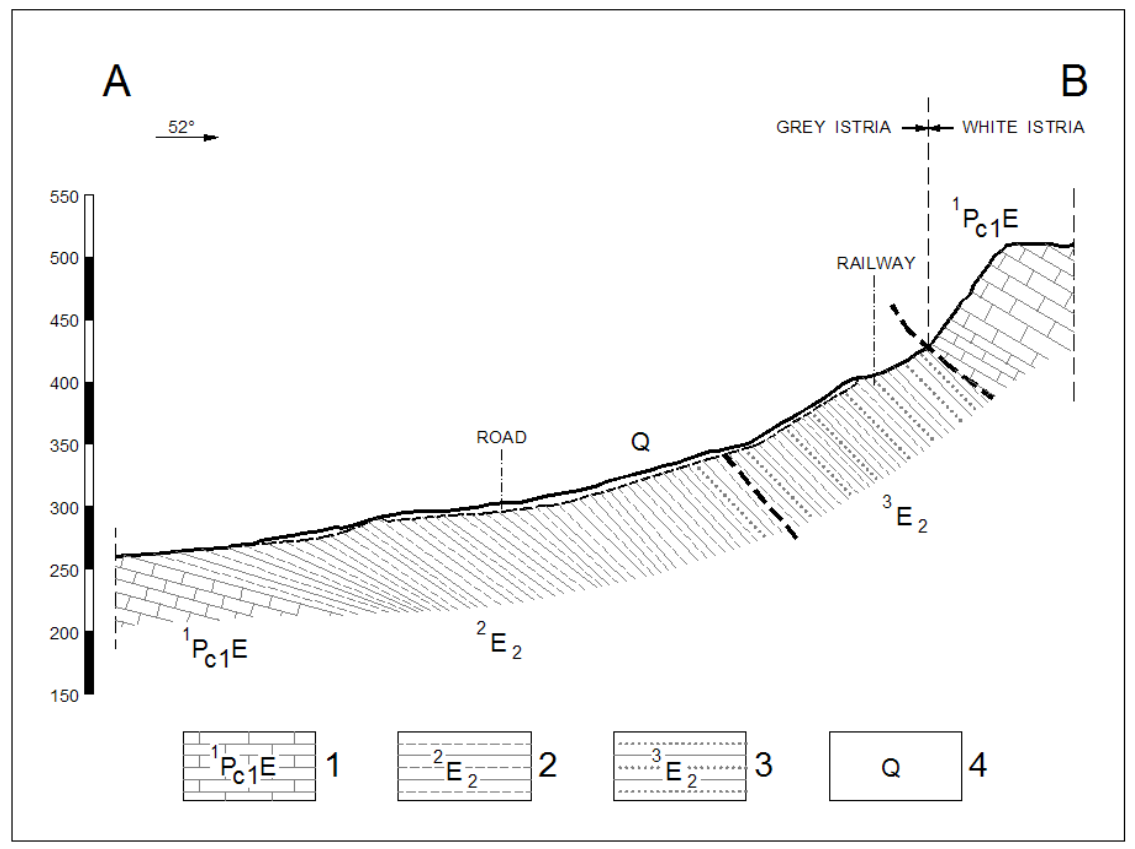

Figure 2: Geological cross-section (1. Paleogene limestones; 2. Paleogene marls; 3. Paleogene flysch; 4. Quaternary deposits).

The kinematics of the structural elements on the margin between the overthrust carbonate unit, the Ćićarija Mountain, and the Paleogene flysch basin, is based on the relation of the relatively rigid (carbonate rocks) and relatively ductile (flysch rock complex) media during simultaneous deformations. The effects of the deformations are most distinctive at the contact (overthrust zone) between the limestone and flysch rock complex. That is the reason why the relatively rigid limestone rock blocks are pushed into the more ductile flysch rocks. Recent gravitational sliding of huge carbonate rock blocks over the flysch bedrock is also visible.

The flysch bedrock complex formed by turbidite sedimentation model, is lithologically very heterogeneous because of the frequent vertical and lateral alternations of diverse lithological sequences: marls, siltstones, fine-grained sandstones, as well as very distinctive layers of calcarenites. Unlike the 
karstificated limestone rocks on the cliffs and the elevation, the flysch bedrock is covered by Quaternary deposits, except in the isolated areas were the erosion is more expressed. At the foot of the cliffs, the coarse-grained fragments originating from the cliffs have mixed with the silty clay from the flyschweathering zone to form few-meter-long slope deposits at the foot of the southwestern margin of the Ćićarija Mountain, Fig. 2.

\section{Causes and triggering mechanisms of debris flows}

The debris flows on the flysch deposits of North Istria are not a typical instability phenomenon. Typically are occurrences of small landslides when the weathering zone or the deluvial clayish cover begins to slide mostly in contact with the flysch bedrock [3]. These landslides mostly affect the smaller areas of the slope and are, in principle, caused by unfavorable hydrologic conditions very often in combination with human activity on the slopes.

Debris flows in the flysch deposits of North Istria appear at locations that are geomorphologically and geologically predisposed to such occurrences. The debris flows appear in fossil ravines deeply cut into the flysch bedrock and filled over time with clayly or silty materials brought by gravity from the hypsometrically higher parts of the slope. These slope formations are formed by mixtures of coarse-grained limestone fragments and silty clay as the result of the weathering and erosion of the flysch bedrock. The filling of ravines causes a shift in surface flows, whereas the underground flows in the cover deposits are still active because they are predisposed to such activity by the location of the low-permeable flysch bedrock. In case of intensive rainfalls occurring in a relatively short period of time, the clay cover gets saturated and the underground water level in the slope increases. Because of the low permeability of the silty clay deposits, the flow is very slow, especially in the lower parts of the slope consisting mostly of clayly materials. This causes the increase in the water level in the upper parts of the slopes that consist mainly of coarse-grained silty materials $[4,5]$. The saturation of deposits in filled ravines and the increase in the underground water level are the main triggering mechanisms of debris flows due to the following:

- The increase in water content of clayly deposits causes reduction in cohesive forces between the particles and a decrease in strength. Due to the increase of water content, the liquid limit $\left(\mathrm{w}_{1}\right)$ is reached in certain parts of deposits, which causes the complete loss of residual strength of the liquefied layer.

- The increase in the underground water level causes an increase in pore pressure, a reduction of effective stresses, and a decrease in the strength of the cover.

- The increase in the underground water level in the upper parts of the slope causes saturation and increase in volume of the capillary elevations above the underground water level. This causes additional load on the upper parts of the slope. 
- The increase in the underground water level causes a significant increase in hydrodynamic forces that deviate from the gravitational forces along the slope.

All previously described causes together trigger the occurrence of instability. The triggering mechanism and the type of instability caused depend on the magnitude of some of the previously described phenomena. The most frequent type of instability is the activation of a debris flow due to increase in water content exceeding the liquid limit, and the occurrence of solifluction, the fluidification of clayly layer, after the complete loss of shear strength [6]. Fluidification mainly occurs in the thin layer of the clayly cover at the location where it meets the flysch deposits formed by the weathering of the flysch bedrock. The upper layers of slope deposits, although saturated, do not liquefy due to their coarse-grained granulometric composition. Debris flows are manifested as the flows of the thin liquefied layer that carries a layer of unliquefied mass, mostly of coarse-grained granulometric composition [7]. The debris mass segregates and accumulates at the head of debris flow [8].

\section{Description of instability}

The debris flow is situated in the Krbavčići village area northeastern of the city of Buzet. The slope on which the studied landslide is located has an average dip of $12^{\circ}$ on the lower part of the slope, and of $30^{\circ}$ on the upper part. The studied area is completely covered with Quaternary deposits: a mixture of coarse-grained fragments originating from limestone cliffs and fine-grained silty clay originating from the weathering zone of the flysch bedrock. The outcrops of the flysch bedrock are partly visible in road cuts.

At the location of the Krbavčići debris flow, the instability occurred on several occasions before as well. The first larger soil movements were registered in 1961 after which a calm period ensued. A more significant sliding at the location was activated again in the night between the $30^{\text {th }}$ and $31^{\text {st }}$ of January 1979 after intensive rainy periods. The landslide affected the slope area of $40 \mathrm{~m}$ in width and $250 \mathrm{~m}$ in length, Fig. 3. The landslide carried away the body of the existing road in the length of $30 \mathrm{~m}$. The landslide mass was carried down the slope and covered the existing vineyards at the toe of the landslide. According to the accepted classification system, the described instability is characteristic of multiple retrogressive landslides that develop from the toe of the landslide along the slope. As the landslide depends on the geological fabric, and considering its location and movements, it can also be classified as a translational landslide [9]. According to the landslide activity, it is classified as a reactivated landslide [10]. The landslide was stabilized naturally assuming a stable position again. The road was reconstructed by building a viaduct over the landslide with deep foundations on bored piles.

In January 2003, after the intensive rainy periods a debris flow was formed by the activation of the clayly cover on the slope, in the ravine above the road in the length of $160 \mathrm{~m}$, Fig. 3. The sliding was caused by the increase in water level in the clayly deposits in the cover that caused the reaching of the liquid consistency 
of clayly mass. The speed of the landslide grew from $10 \mathrm{~cm} /$ day to more than 5 $\mathrm{m} /$ day. The sliding mass came very close to the viaduct passing over the old landslide. It was feared that the construction might be damaged. However, prompt intervention measures were taken and the sliding mass near the viaduct was removed. More than $25,000 \mathrm{~m}^{3}$ of the sliding body was carried away and the viaduct was saved. The stoppage of rainfall and the ensuing dry period helped stop the mass movements by reducing the inflow of water into the slide mass. The upper parts of the slope are still moving and the complete remedial works on the slope have not been performed yet.

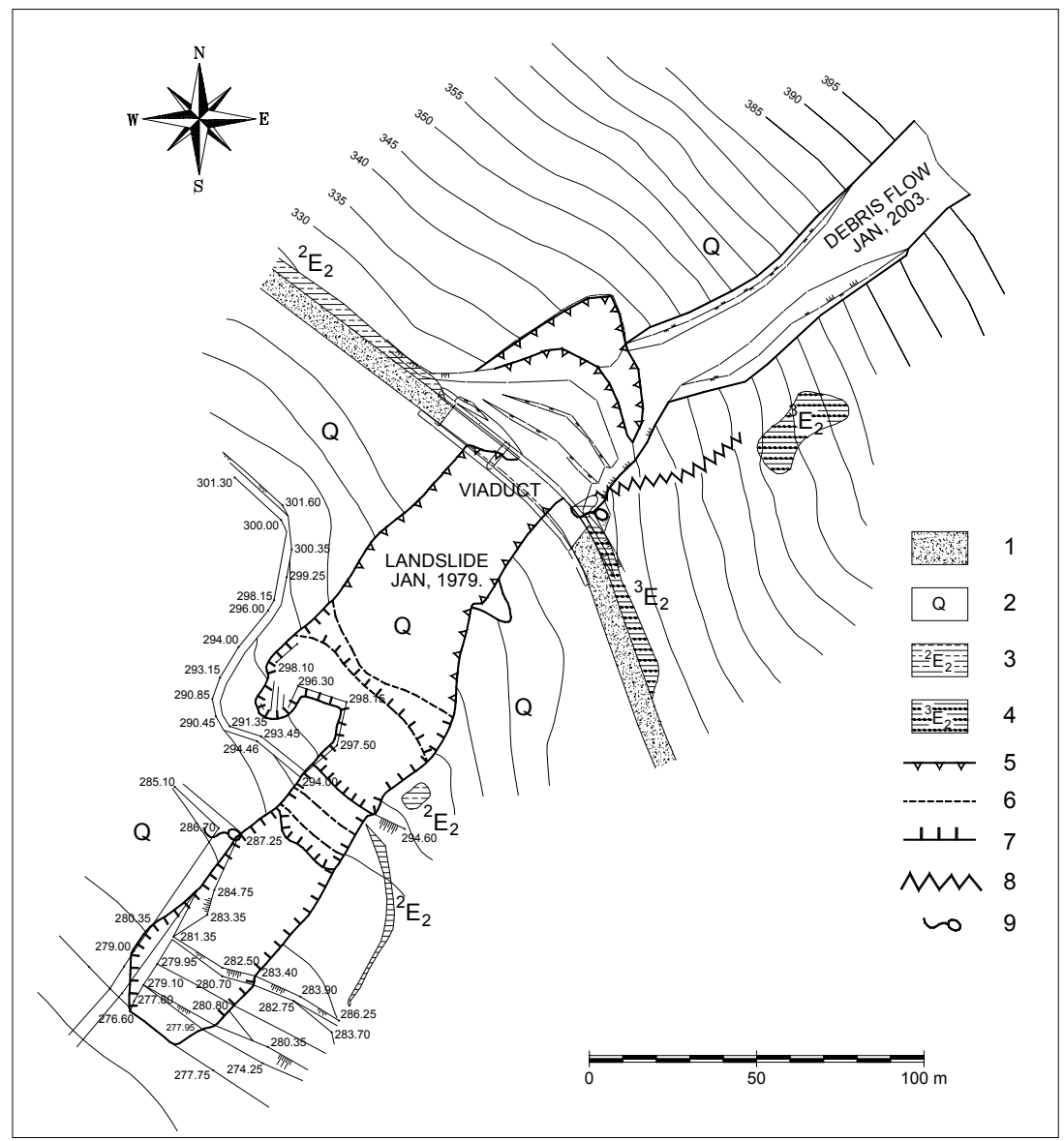

Figure 3: Geological map of landslide, January, 1979 and debris flow, January, 2003 (1. Road embankment; 2. Quaternary deposits; 3. Paleogene flysch outcrop; 4. Paleogene marls outcrop; 5. Soil scarp; 6. Shear fracture; 7. Compression fracture; 8. Ravine; 9. Periodical spring). 
In accordance with geological mapping and the results of investigation drilling, the space and thickness of the displaced slide mass was estimated. The geometry of the landslide is described according to the WP/WLI Suggested Nomenclature for Landslides [11], Table 1.

Table 1: Dimensions of slide instabilities.

\begin{tabular}{|l|ccc|}
\hline \multicolumn{1}{|c|}{ Dimension of instability } & \multicolumn{3}{c|}{ Instability } \\
\cline { 2 - 4 } & January, 1979 & January, 2003 & Total \\
\hline Total landslide length, L (m) & 242 & 140 & 347 \\
Displaced mass length, Ld (m) & 240 & 137 & 345 \\
Rupture surface length, Lr (m) & 220 & 130 & 310 \\
Dispalced mass width, Wd (m) & 55 & 40 & 55 \\
Rupture surface width, Wr (m) & 45 & 50 & 50 \\
Dispalced mass depth, Dd (m) & 5 & 4 & 5 \\
Rupture surface depth, Dr (m) & 6 & 16 & 16 \\
Total height from tip to crown, $\Delta \mathrm{H}(\mathrm{m})$ & 62 & 69 & 117 \\
\hline
\end{tabular}

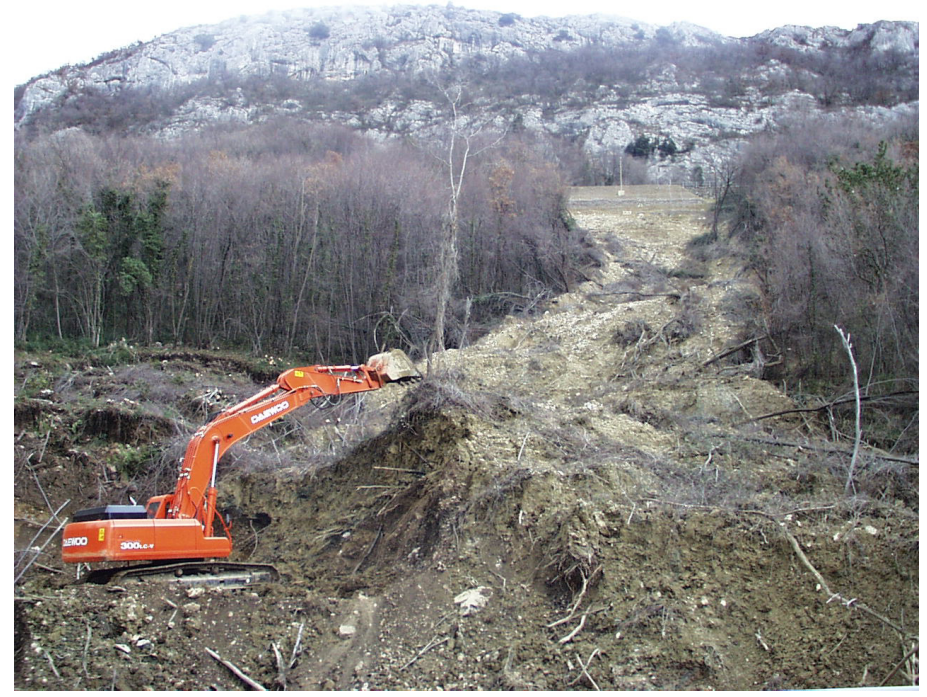

Figure 4: $\quad$ Photo of the debris flow Krbavčići (Photo: Arbanas, Ž., Jan, 2003).

\section{Discussion}

The sliding that occurred in January 1979 was activated after a period of intensive rainfalls during October and November 1978. The intensity of rainfalls is shown in Table 2 that presents rainfalls as recorded in the Abrami meteorological station near the city of Buzet located $10 \mathrm{~km}$ away from the studied area. Due to low water permeability of clayly deposits, the flow was very slow in the lower parts of the slopes where the slope formations are mostly of clayly composition and in contact with the flysch bedrock. This caused the increase in water level of the upper parts of the cover. The exceeding of the 
material strength in the weathering zone just above the flysch bedrock, caused instability in the form of a multiple retrogressive landslide. By analyzing the shape of the landslide, especially its lower segment, it is probable that a debris flow occurred as well, Fig. 3. The fluidification of the weathering zone probably occurred above the flysch bedrock and caused large movements of the slide mass at the toe of the landslide.

Table 2: Presentation of intensity of rainfalls before and during the period of instability as recorded in the Abrami meteorological station.

\begin{tabular}{|c|rrrrrrrrrrrr|r|}
\hline \multicolumn{10}{|c|}{ Rainfall (mm) } \\
\hline Year & \multicolumn{1}{|c|}{ Jan. } & \multicolumn{1}{|c|}{ Feb. } & Mar. & \multicolumn{1}{|c|}{ Apr. } & May & Jun. & Jul. & Aug. & Sep. & Oct. & Nov. & Dec. & Total \\
\hline 1978 & 157.3 & 72.2 & 87.1 & 96.1 & 147.6 & 79.1 & 51.8 & 97.7 & 79.0 & 100.2 & 60.5 & 151.8 & 1180.4 \\
2002 & 17.5 & 106.0 & 6.0 & 113.5 & 121.2 & 113.2 & 65.9 & 174.2 & 127.7 & 111.8 & 202.6 & 38.7 & 1198.3 \\
\hline Average 1963-2003 & 83.5 & 70.5 & 81.7 & 92.6 & 89.6 & 107.4 & 77.1 & 98.5 & 118.1 & 119.1 & 130.3 & 95.4 & 1163.7 \\
\hline
\end{tabular}

The debris flow that occurred in January 2003 was activated in November 2002 after the period of intensive rainfalls. Because of the low water permeability of clayly deposits in the ravine, a longer period of time was needed to saturate the area above the road bridged over by a viaduct. The movements appeared in the beginning of December 2002. They were manifested by the appearance of tension fractures by the end of December 2002 when the speed of the movements significantly increased. All this resulted in January 2003 in exceeding the material strength limit and a significant increase of the speed of mass movements. The instability that occurred corresponds to the accepted definitions of debris flows in all its segments [12, 13, 14, 15, 16, 17].

Table 3: Geotechnical properties of cover deposits.

\begin{tabular}{|c|c|cc|}
\hline Geotechnical property & Symbol (unit) & Min. & Max. \\
\hline Liquid Limit & $\mathrm{w}_{\mathrm{l}}, \%$ & 28,80 & 62,70 \\
Plastic Limit & $\mathrm{w}_{\mathrm{p},} \%$ & 18,00 & 26,70 \\
Plasticity Index & $\mathrm{I}_{\mathrm{p}} \%$ & 10,30 & 30,60 \\
Cohesion & $\mathrm{c}, \mathrm{kN} / \mathrm{m}^{2}$ & 2,5 & 34,5 \\
Internal Friction Angle & $\Phi^{\circ}$ & 12,4 & 31,2 \\
\hline
\end{tabular}

The triggering mechanism of the landslide and the activation of the debris flow depend on the geotechnical properties of the materials in the cover. The following geotechnical properties that influence the occurrence of instability were established through lab analyses of the samples of the cover taken from the slide mass, Table 3.

The geotechnical properties of the cover depend directly on the mineralogical properties of clayly materials. Therefore, the analysis of the mineralogical properties of clayly materials was also conducted. The analysis was carried out using powder X-ray diffraction approach (XRD). Samples taken from different layers of deposits on the slope, at the landslide and the nearby area were analyzed, Table 4 . The analysis showed a higher concentration of clay mineral in the sample taken from the landslide in relation to other analyzed samples. A 
higher concentration of muscovite and illite has also been noticed in the landslide area. Muscovite and illite are clay minerals that determine the behavior of low-plastic deposits (CL). They are characterized by the low liquid limit, in other words they liquefy even in the presence of lower water content that is quite easily reached during intensive rainfalls.

Table 4: Mineralogical composition of materials in the slope.

\begin{tabular}{|c|c|c|c|c|c|c|c|c|c|}
\hline \multirow{2}{*}{$\begin{array}{c}\text { Sample } \\
\text { No. }\end{array}$} & \multirow{2}{*}{ Origin } & \multicolumn{8}{|c|}{ Clay Mineral } \\
\hline & & Calcite & Quartz & Plagioclase & K-felspar & Micas & Chlorite & Vermiculite Smectite & Total Clay Minerals \\
\hline 1 & Bedrock & 36 & 10 & + & & 20 & & 10 & $\sim 55$ \\
\hline 2 & Bedrock & 48 & 10 & $<5$ & & 12 & + & 5 & $\sim 40$ \\
\hline 3 & Bedrock & 51 & 10 & + & & 10 & & 5 & $\sim 40$ \\
\hline 4 & Weathering zone & 33 & 13 & + & & 15 & & 10 & $\sim 55$ \\
\hline 5 & Slide body & & 26 & $<5$ & + & 25 & & 10 & $\sim 70$ \\
\hline 6 & Bedrock & 32 & 18 & 5 & + & 15 & & 10 & $\sim 45$ \\
\hline 7 & Slide body & 13 & 23 & 5 & + & 20 & & 10 & $\sim 60$ \\
\hline
\end{tabular}

\section{Conclusions}

The debris flows in the flysch zone of North Istria are not typical instability phenomena. The development of the described mass movements was predisposed by the position of the long and narrow ravine at the studied location. The fragments originating from the cliffs and the silty clay originating from the flysch weathering zone were deposited in this geomorphological trap and have formed over the course of thousands of years few meter thick relatively unstable deposits.

The filling of ravines causes a shift in surface flows, whereas the underground flows in the cover are still active. In the periods of intensive rainfalls occurring in a relatively short period of time, the potential landslide body gets saturated and the underground water level in the slope increases. The saturation in deposits in filled ravines and the increase in the water level represent the main causes of occurrence of debris flows. The increase in water content of clayly deposits causes reduction in cohesive forces between the particles and a decrease in strength. Due to the increase in water content, the liquid limit $\left(\mathrm{w}_{1}\right)$ is reached in certain parts of deposits, which causes the complete loss of residual strength of the liquefied layer. Fluidification mainly occurs in the thin clayly layer that is in contact with the flysch bedrock. The upper layers of slope deposits, although saturated, do not liquefy due to their coarse-grained granulometric composition and a higher concentration of rock fragments. The landslide mass segregates and accumulates at the head of the debris flow.

\section{Acknowledgements}

The authors thank Professor Dragutin Slovenec, Faculty of Mining, Geology and Petroleum Engineering, University of Zagreb, Croatia, for conducting a mineralogical analysis and providing an interpretation of the obtained results. 


\section{References}

[1] Marinčić, S. \& Matičec, D., Tectonic and kinematic model-an Istrian model. Geološki vjesnik, 44, pp. 247-268, 1991.

[2] Mihljević, D. \& Prelogović, E., Structural-geomorphological characteristic of the mountain ranges Učka \& Ćićarija. Proc. of the Int. Symp. Geomorphology and Sea, Mali Lošinj, pp. 13-24, 1992.

[3] Arbanas, Ž., Benac, Č \& Jardas, B., Small landslides on the flysch of Istria. Proc. $3^{\text {th }}$ Conf. Slovenian Geotech., 1, Sloged: Ljubljana, pp. 81-88, 1999.

[4] Picarelli, L., Urciuoli, G., Ramondini, M. \& Comenga, L., Main Features of Mudslides in Tectonised Highly Fissured Clay Shales, Landslides, 2(1), pp. 15-30, 2005.

[5] Malet, J.-P., Laigle, D., Remaitre, A. \& Maquaire, O., Triggering conditions and mobility of debris flows associated to complex earth flows. Geomorphology, 66, pp. 215-235, 2005.

[6] Lorenzini, G. \& Mazza, N., Debris Flows, Phenomenology and Rheological Modelling, WIT Press: Southampton, Boston, pp. 1-202, 2004.

[7] Takahashi, T., Initiation and Flow of Various Types of Debris-flow. Debris Flow Hazard Mitigation: Mechanics, Prediction and Assessment, eds. Wieczorek \& Naeser, Balkema: Rotterdam, pp. 15-25, 2000.

[8] Takahashi, T., Debris Flow, Monograph Series of IAHR, IAHR: Rotterdam, pp.165, 1991.

[9] Cruden, D.M \& Varnes, D.J., Landslide Type and Processes. Landslides: Investigation and Mitigation, Special report 247, eds. A.K. Turner \& R.L. Schuster, National Academy Press: Washington, D.C., pp. 36-75, 1996.

[10] Keaton, J.R. \& Degraff, J.V., Surface Observation and Geologic Mapping. Landslides: Investigation and Mitigation, Special report 247, eds. A.K. Turner \& R.L. Schuster, National Academy Press: Washington, D.C., pp. 194-195, 1996.

[11] IAEG, Suggested Nomenclature for Landslides. Bulletin IAEG, 41, pp. 13$16,1990$.

[12] Varnes, D.J., Landslide Type and Process. Landslide \& Engineering Practice, ed. E.B. Eckel, Highway Research Board: Special Report 21, 1958.

[13] Takahashi, T., Debris Flow, Ann. Rev. Fluid Mechanics, 13, pp. 57-77, 1981.

[14] Coussot, P., Rheologie des Laves Torrentiales. Collection Etude, Serie Montagne, 5, pp. 415, 1992.

[15] Coussot, P. \& Meunier, M., Recognition, Classification and Mechanical Description of Debris Flow. Earth-Sci. Rev., 40, pp. 209-227, 1996.

[16] Glade, T., Linking debris-flow hazard assessment with geomorphology. Geomorphology, 66, pp. 189-213, 2005.

[17] Wieczorek, G. \& Glade, T., Climatic Factors Influencing Triggering of Debris Flows. Debris Flow Hazard and Related Phenomena, eds. M. Jakob, \& O. Hungr, Springer: Heidelberg, pp. 325-362, 2005. 